\title{
信号交差点における左折交通に及ぼす横断歩行者及び自転車の特性と定量化について* Characteristics and Quantitative Analysis of Crossing Pedestrian and Bicycles Affecting the Left-turn Flow at Signalized Intersections*
}

\author{
河合芳之 ${ }^{* *} \cdot$ 片倉正彦 $* * *$. 鹿田成則 $\mid * * * *$ ·大口敬 $* * * * *$ \\ By Yoshiyuki KAWAI** Masahiko KATAKURA*** ${ }^{*}$ Shigenori SHIKATA ${ }^{* * *} \cdot$ Takashi OGUCHI ${ }^{* * * * *}$
}

\section{1.はじめに}

都市内街路における交通啮滞は, 主要な信号交差 点で発生している。信号交差点の流入部は, 最外側 車線を直進・左折混用車線とし，横断歩行者・自転 車 (以下：横断歩行者等）と同一現示で処理するこ とが一般的である。このような最外側車線は, 横断 歩行者等の影響により左折車両の閉塞が生じ, 併せ て直進車両の消極的な車線選択による交通容量の低 下が見られる。

左折交通の飽和交通流率に及ほすす影響のうち幾何 構造（転向半径）について筆者らは、すでに定量化 を行っている 1)。左折飽和交通流率は, 横断歩行者 等との交錯により低減する。交錯による影響は青開 始後の時間の推移によって変化し、左折車両は通過 可能な横断歩行者等の間隔が出現するまで停止して いなければならない。横断歩行者等は二方向から横 断歩道上に進入し、左折車両が停止させられる時間 帯はそれぞれの方向で異なる。左折車両と横断歩行 者等との交錯の影響を表現する必要がある。従来、 この点を明示的に具体的に取り扱った研究例はほと んどなく、特に横断歩行者とともに横断自転車を扱 った研究事例はわが国では皆無といってよい。

横断歩行者等と左折車両が交錯する地点における 横断歩行者等の実態とその特性について明らかにし， 横断歩行者等の横断挙動の定量化を行った。信号待 ちの状態から発進する歩行者等の流率は, 滞留人数 を変数とした関数で近似でき, 横断距離を変数とし た拡散現象で表すことを示した。さらに、横断歩行 者等の自転車交通量を用いて，最初に左折車両と交 錯する地点に到達する歩行者等の属性の推定手法を 案出し，この歩行者等の横断速度算出手法の導出を

* キーワーズ: 横断歩行者,自転車,左折交通容量,信号交差点

** 正員 博(工) 株式会社 公共計画研究所

*** 正員 工博 東京都立大学大学院工学研究科土木工学専攻

**** 正員工修 同上

***** 正員 博(工) 同上

干 150-0002 東京都渋谷区淽谷3-11-2

Tre 03-3407-2055 FAX03-3407-2015
行った。これらの結果を統合して、横断歩行者等が 左折車両を閉塞する時間の算出方法を確立した。

\section{2. 既存研究のレビュー}

横断歩行者等による影響要因は、左折飽和交通流 率の補正率の形で表現することが一般的であり，日 本および欧米において種々な手法が案出されている。

わが国では、シミュレーション（横断歩行者の前 方・後方ギャップより左折車の停止と通過を表現） を用いて横断歩行者と交錯する左折車の最大流率を 求め、横断歩行者のない左折の交通容量との比に基 づいて補正率を算出したもの $\left.{ }^{2}\right)$ と、左折交錯点（コ ンフリクトゾーン)における歩行者交通量を歩行者 密度に変換し, これから左折の停止確率求めて補正 率としたものがある3，4)。

欧米では，左折交通容量を算出する際、横断歩行 者の影響を補正率で表し、この補正率を算出する方 法に左折交錯点を適用した方法を主として用いてい る。左折交錯点という概念は，1966年にオーストラ リアのGordon\&Miller，1975年に西ドイツのKrauss \&Trappらによって提案されたものである。スェーデ ン交通容量マニュアル5) は, 横断歩行者の発生をポア ソン分布と仮定し，左折交錯点において左折車両が 通行できる歩行者ギャップを設定して左折交通容量 を算出している。また，Tarkoら ${ }^{6)}$ は，歩行者交通量 と左折交錯点における左折車両の閉塞時間を回帰モ デルにより定式化しこれにより左折交通容量を算出 している。このモデルは、現行のドイツの交通容量 マニュアルであるHBS20017)で採用されている。最近 の研究では.Mi lazzoら ${ }^{8) 9}$ が，横断歩行者と自転車専 用車線を通行する自転車の左折交錯点占有時間比率 を補正率とし，飽和交通流率を算出している。一方， Teply (10) $^{(0)}$, 歩行者交通量と左折飽和交通流率の関 係を回帰モデルにより算出している。 


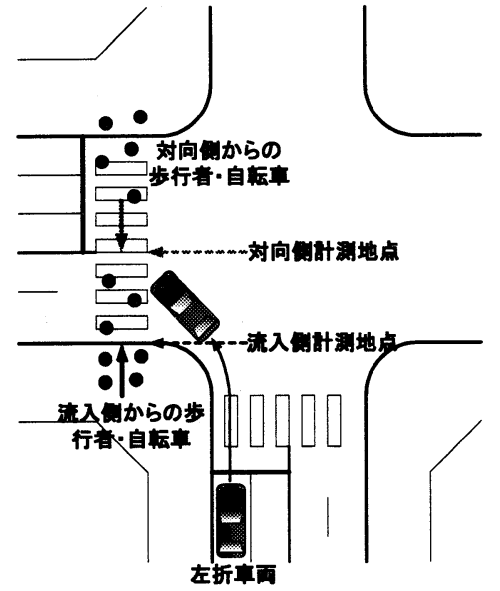

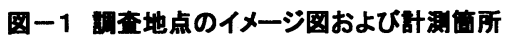

本研究では 東京都内の業 務・商業中心 地区の中から 6 箇所の交差 点において観 測を行った。 観測方法は, 高所よりビデ オカメラによ って撮影した。 調査方法は,

図一 1 に示す ように対象横 断歩道に着目し、サイクル単位で歩行者・自転車の 別に流入側・対向側計測断面の通過時刻を計測した。 併せて、この時の信号現示時間を記録した。調査時 間は，各地点 4 時間から 6 時間である。

各調査地点における実測結果の概要および横断歩 道の諸元を表一 1 に示す。実測結果は，合計で 23,38 5 人であり, 各調査地点の解析時間は, 3.6 時間から 5. 8時間である。各調査地点における時間平均歩行者等 数は, 332 人/時から 1,475 人/時, 自転車混入率は, 4.8\%から $44.9 \%$ でった。

\section{4. 歩行者等の横断挙動モデルの概念}

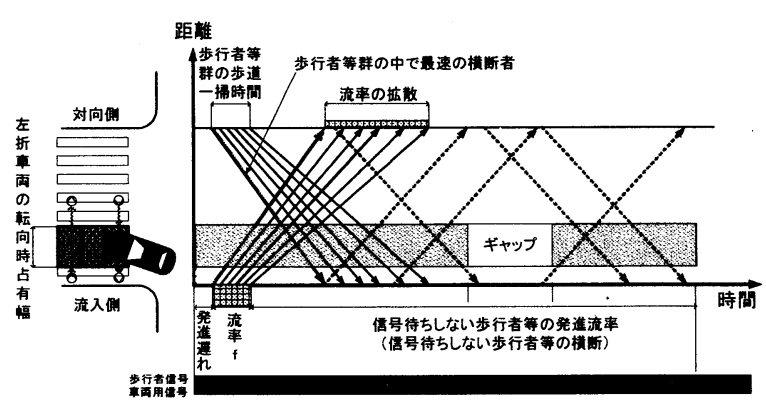

図一2 モデルの概念図

本研究は, 横断歩行者等の横断挙動について時間 を変数としたモデルを構築した。本研究で考案した モデルは，図一 2 に示すように横断歩行者等と左折 車両が横断歩道上で交錯する場所を交錯エリアとし、 横断歩行者等が左折交錯エリアを通過する時刻を推 定するための横断挙動をモデル化した。本モデルで は、図ー1に示すように、左折巻き込み側歩道から 発進する歩行者を流入側歩行者とし、対向側歩道か ら発進する歩行者を対向側歩行者と定義する。また、 本研究で用いる群は、信号待ちする横断歩行者等の 横断時の集合を表す。モデルの概要は, 以下に記述 するとおりである。

信号待ちで歩道上に滞留した歩行者等群は, 青表 示開始時刻から発進遅れ時間の後, 発進する。信号 待ちの流入側横断歩行者等群が流出し左折交錯エリ アを通過している間は, 左折車両は通過できない。 信号待ちの流入側歩行者等群が流出し終わった後、 信号待ちしない流入側歩行者等は, 到着分布に従っ て横断を行う。

一方, 対向側の歩道縁石線を発進する歩行者等は, 流入側歩行者等群と同様の発進遅れを伴い，横断を

表一 1 実測結果の概要および横断歩道等の諸元

\begin{tabular}{|c|c|c|c|c|c|c|c|c|c|c|c|c|c|c|c|}
\hline & & 全歩行者 & $\begin{array}{c}\text { 歩行者数 } \\
\text { (人) }\end{array}$ & 自転車数 & \begin{tabular}{|c|} 
信号待ち \\
歩行者等 \\
数(入) \\
\end{tabular} & \begin{tabular}{|l|} 
信号待ち \\
無歩行者 \\
等数(人)
\end{tabular} & $\begin{array}{l}\text { 解析 } \\
\text { 時間 } \\
\text { (時) } \\
\end{array}$ & \begin{tabular}{|c} 
時間当り歩 \\
行者数 ( \\
/時)
\end{tabular} & $\begin{array}{l}\text { 平均サ } \\
\text { イクル } \\
\text { 長(秒) }\end{array}$ & \begin{tabular}{|c|} 
平均青 \\
時間 \\
(秒)
\end{tabular} & $\begin{array}{c}\text { 横断歩 } \\
\text { 道幅 } \\
(\mathrm{m})\end{array}$ & $\begin{array}{l}\text { 自転車 } \\
\text { 横断带 } \\
\text { 幅員 }(\mathrm{m}) \\
\end{array}$ & $\begin{array}{c}\text { 横断带 } \\
\text { 幅員合 } \\
\text { 計(m) } \\
\end{array}$ & \begin{tabular}{|} 
全横断 \\
距離(m)
\end{tabular} & \begin{tabular}{|l} 
対向側 \\
横断距 \\
離(m) \\
\end{tabular} \\
\hline \multirow[t]{2}{*}{ 鼌戸4丁目 } & 流入側から & 1,959 & 1,146 & 813 & 1,356 & 603 & 5.8 & 340 & \multirow[t]{2}{*}{138} & \multirow[t]{2}{*}{48.5} & \multirow[t]{2}{*}{4.25} & \multirow[t]{2}{*}{1.75} & \multirow[t]{2}{*}{6.00} & \multirow[t]{2}{*}{18.00} & \multirow[t]{2}{*}{10.70} \\
\hline & 対向側から & 1,694 & 934 & 760 & 1,045 & 649 & 5.8 & 294 & & & & & & & \\
\hline \multirow[t]{2}{*}{ 小川町 } & 流入側から & 1,330 & 1,175 & 155 & 890 & 440 & 3.6 & 372 & \multirow[t]{2}{*}{132} & \multirow[t]{2}{*}{45.1} & \multirow[t]{2}{*}{4.20} & \multirow[t]{2}{*}{1.75} & \multirow[t]{2}{*}{5.95} & \multirow[t]{2}{*}{24.00} & \multirow[t]{2}{*}{13.50} \\
\hline & 対向側から & 1,277 & 1,145 & 132 & 887 & 390 & 3.6 & 357 & & & & & & & \\
\hline \multirow[t]{2}{*}{ 神保町 } & 流入側から & 3,942 & 3,754 & 188 & 2,670 & 1,272 & 5.4 & 733 & \multirow[t]{2}{*}{132} & \multirow[t]{2}{*}{47.8} & \multirow[t]{2}{*}{4.40} & \multirow[t]{2}{*}{1.70} & \multirow[t]{2}{*}{6.10} & \multirow[t]{2}{*}{22.50} & \multirow[t]{2}{*}{13.05} \\
\hline & 対向側から & 3,989 & 3,782 & 207 & 2,996 & 993 & 5.4 & 742 & & & & & & & \\
\hline \multirow[t]{2}{*}{ 西䉾鴨 } & 流入側から & 915 & 627 & 288 & 643 & 272 & 4.9 & 189 & \multirow[t]{2}{*}{130} & \multirow[t]{2}{*}{33.6} & \multirow[t]{2}{*}{3.50} & \multirow[t]{2}{*}{1.40} & \multirow[t]{2}{*}{4.90} & \multirow[t]{2}{*}{14.35} & \multirow[t]{2}{*}{8.20} \\
\hline & 対向側から & 941 & 635 & 306 & 645 & 296 & 4.9 & 194 & & & & & & & \\
\hline \multirow[t]{2}{*}{ 日本橋 } & 流入側から & 2,712 & 2,510 & 202 & 1,541 & 1,171 & 5.0 & 538 & \multirow[t]{2}{*}{132} & 61.8 & 6.10 & 0.00 & 6.10 & 22.00 & 12.00 \\
\hline & 対向側から & 2,805 & 2,635 & 170 & - & - & 5.0 & 557 & & & & & & & \\
\hline 本八丁堀 & 流入側から & 854 & 692 & 162 & 504 & 350 & 5.5 & 156 & 132 & 51.6 & 4.90 & 2.00 & 6.90 & 22.10 & 12.60 \\
\hline & 対向側から & 960 & 800 & 160 & 631 & 329 & 5.5 & 176 & & & & & & & \\
\hline & 計 & 23,378 & 19,835 & 3,543 & 13,808 & 6,765 & 60 & - & - & - & - & - & - & - & - \\
\hline
\end{tabular}

※ 青時間は, 亀戸4丁目と西巣鴨については歩行者青時間であり, その他の地点は, 車両用信号の青時間である。

日本橋の対向側については, 撮影上の制約から信号待ちの有無については読み取りができなかった。 
開始する。しかしながら，対向側歩行者等群は，最 初に左折交錯エリアに到達するまでに距離があるた め, 左折交錯エリアでは，対向側歩行者等群に拡散 が生じると考えた。

対向側歩行者等群が最初に左折交錯エリアに到達 する時間は，対向側歩行者等群の中で最も速度の高 い歩行者または自転車が左折交錯エリアに到達する 時間である。その後, 拡散した対向側歩行者等群が 左折交錯エリアを通過している間も左折車は通過で きない。信号待ちの対向側歩行者等群が左折交錯工 リアを流出し終わった後、信号待ちしない対向側歩 行者等は, 到着分布に従って横断を行う。

左折車両が通過可能な時間は，

(1)左折交錯エリアを流入側歩行者等群の最終横 断者通過終了時刻と、対向側歩行者等群の先頭者 到着時刻の時間差が, 左折車両通過に必要なギャ ップ以上の時間

(2)対向側歩行者等群の最終横断者が左折交錯エ

リアを通過終了時刻後の時間

である。

本研究では、横断歩道幅員、横断歩道長および歩 行者等交通量が調査地点毎に異なることから、横断 歩行者等の横断特性を表す指標として発進流率を用 いた。発進流率 $f$ は，横断歩道幅員 $1 \mathrm{~m}$ 当りに換算 した横断歩行者等の滞留人数を歩行者等群の最速歩 行者等と最遅歩行者等の時間差で除した値「(人/

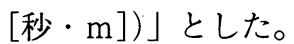

\section{5. 解析結果}

\section{（1） 流入側歩行者等群の特性について}

滞留人数 4 人以下では，横断歩道上を併進するケ ースでは発進流率は高く，一方縦列で発進するケー スでは発進流率は低くなり，発進流率のばらつきが 大きい結果となった。帯留人数 5 人以上では横断歩 道幅員の物理的制約から縦列で発進するため，滞留 人数と発進流率の間に相関関係がみられ、滞留人数 の増加に伴い発進流率が高くなる傾向が見られた。 そこで,滞留人数 5 人以上と 4 人以下では等質では ないと考えクラス分けを行って解析を行うこととし た。

初めに流入側歩行者等群の発進流率の結果を表一
表 -2 流入側歩行者等群の発進流率

\begin{tabular}{|c|c|c|c|}
\hline & 発進流率 & $\vec{\tau}-夕$ 数 & 㯖準偏差 \\
\hline 奄戸4丁目 & 0.31 & 135 & 0.18 \\
\hline 小川 町 & 0.35 & 88 & 0.12 \\
\hline 神保町 & 0.51 & 149 & 0.21 \\
\hline 西单鴨 & 0.43 & 63 & 0.22 \\
\hline 日本端 & 0.36 & 124 & 0.11 \\
\hline 本八丁堀 & 0.25 & 38 & 0.1 \\
\hline 計 & 0.38 & $\overline{597}$ & 0.19 \\
\hline
\end{tabular}

2 に示す $(5$ 人以上の滞留があったサイクルを抽出)。 歩行者等の発進流率を調査地点毎にみると, 平均 值で0.25(人/[秒・m]) から0.51 (人/ $[$ 秒・m]) であり, 歩行者等交通量の多い地点で発進流率が高 い結果となり, 滞留人数が増加すると発進流率も増 加する傾向が伺えた。実測結果に既存研究の実測值 ${ }^{1}$ 1)を補完し，地点合計 $(\mathrm{n}=636)$ のサイクル毎の滞留人 数と発進流率の相関図を作成した(図- 3 参照)。

相関係数は, $R=0.57$ であり, 滞留人数が少ない時 は，発進流率のばらつきが大きいものの滞留人数が 多くなるに従って発進流率が高くなりばらつきも小 さくなる傾向がある。以上の理由から, 滞留人数 5 人以上の発進流率は滞留人数を变数とする関数とし た。

$$
f=0.0121 N+0.251(f \text { : 発進流率, } \mathrm{N} \text { : 滞留人数 })
$$

滞留人数 4 人以下の発進流率は, 平均值を用い算 出した。 $f=0.416$ (デー夕数 $: n=139$ )

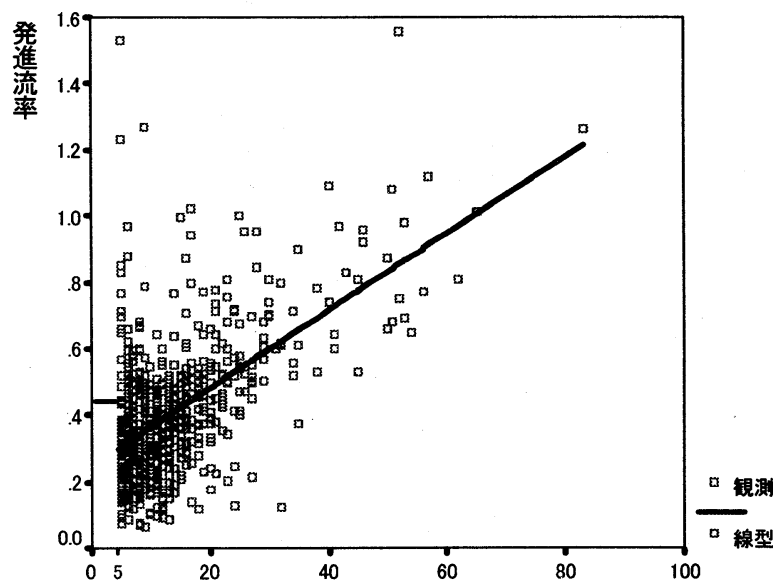

滞留人数

\section{図一３＼cjkstart滞留人数と発進流率の関係}

（2） 流入側歩行者等群のフライング

主要な信号交差点では, 右折交通を処理するため 
に右折専用現示を設置している箇所が多く, 通常, 右折専用現示の次の現示で歩行者に通行権が与えら れるため横断歩行者等は信号開始時刻に従わず横断 を開始する所謂フライング(Jumping the Gun)をす る状況が見受けられる。実測結果を表- 3 に示す。

この結果から，横断する歩行者等でフライングす る比率は少ないものの, サイクル単位でみるとフラ イングのあったサイクル数の比率が高いことが分か る。従って, 実現象を再現する目的から判断して, 歩行者群等の発進にこのフライングの実態を含めて 解析することとした。

\begin{tabular}{|c|c|c|c|c|c|c|}
\hline & $\begin{array}{l}\text { 歩行者 } \\
\text { 等群数 }\end{array}$ & $\begin{array}{c}\text { フライン } \\
\text { グ数 }\end{array}$ & 比率 & $\begin{array}{l}\text { サイク } \\
\text { ル数 }\end{array}$ & $\begin{array}{l}\text { フライング } \\
\text { サ1々ル数 }\end{array}$ & 比率 \\
\hline 再戸4T目 & 1,356 & 34 & $2.5 \%$ & 154 & 25 & $16.2 \%$ \\
\hline 小川町 & 890 & 48 & $5.4 \%$ & 101 & 21 & $20.8 \%$ \\
\hline 神保町 & 2,670 & 164 & $6.1 \%$ & 150 & 46 & $30.7 \%$ \\
\hline 西宩鵬 & 643 & 34 & $5.3 \%$ & 154 & 25 & $16.2 \%$ \\
\hline 日本楅 & 1,541 & 23 & $1.5 \%$ & 140 & 13 & $9.3 \%$ \\
\hline 本八丁堀 & 504 & 11 & $2.2 \%$ & 141 & 7 & $5.0 \%$ \\
\hline
\end{tabular}

表一 3 歩行者等群のフライング数

\section{（3） 流入側歩行者等群の発進遅れ時間}

歩行者青表示開始から流入側歩行者等群の最初の 横断者が横断開始をする時間を集計した。HCM20009) では,この值を 3.2 秒としており, 歩行者等群の左折 交錯点通過時間を推定するためには不可欠なパラメ ータである。

\section{表 -4 信号待ち歩行者の遅れ時時間}

\begin{tabular}{|c|c|c|c|c|}
\hline & & 遅れ秒数 & 標準偏差 & データ数 \\
\hline \multirow{3}{*}{ 亀戸 } & 計 & 0.93 & 1.00 & 154 \\
\hline & 歩行者 & 0.79 & 1.04 & 100 \\
\hline & 自転車 & 1.21 & 0.96 & 54 \\
\hline \multirow{3}{*}{ 小川町 } & 計 & 1.16 & $\overline{2.48}$ & 101 \\
\hline & 歩行者 & 1.17 & 2.21 & 88 \\
\hline & 自転車 & 1.11 & 3.98 & 13 \\
\hline \multirow{3}{*}{ 神保町 } & 計 & 0.01 & 2.20 & 150 \\
\hline & 步行者 & 0.20 & 1.94 & 131 \\
\hline & 自転車 & -1.30 & 3.35 & 19 \\
\hline \multirow{3}{*}{ 西柴鴨 } & 計 & 1.32 & 1.51 & 132 \\
\hline & 歩行者 & 1.47 & 1.52 & 79 \\
\hline & 自転車 & 1.28 & 1.27 & 53 \\
\hline \multirow{3}{*}{ 日本橋 } & 計 & 1.11 & 1.20 & 140 \\
\hline & 歩行者 & 1.11 & 1.24 & 128 \\
\hline & 自転車 & 1.21 & 0.64 & 12 \\
\hline \multirow{3}{*}{ 本八丁堀 } & 許 & 1.65 & 1.92 & 141 \\
\hline & 歩行者 & 1.69 & 2.08 & 111 \\
\hline & 自転車 & 1.52 & 1.21 & 30 \\
\hline 合計 & 計 & 1.01 & - & 818 \\
\hline
\end{tabular}

各地点で歩行者・自転車毎に集計した (表 -4 参照)。 この結果, どの地点においても概ね 1 秒であった。
また，各地点において歩行者と自転車の平均值の差 をt検定したところ，亀戸 4 丁目を除いた地点では， $1 \%$ 水準で有意差がみられなかった。米国では、信 号制御方式として右折先出しが一般的であるため、 横断歩行者等がフライングすることが事実上困難で あるのに対して、我が国では、信号制御方式の違い によりフライングが相当数観測され、発進遅れ時間 は、米国に比べ小さいことが示された。このことか ら歩行者等群の発進遅れ時間は, 歩行者・自転車に 関わらず1秒とした。

\section{（4） 対向側歩行者等群の拡散}

対向側歩行者等群の発進流率が横断距離を変数と した関数で表すことが可能であると考え、横断歩道 の縁石からの距離に応じた発進流率の変化（流率） を分析した。本研究では、対向側の歩行者等群が発 進した後に車道中央線を通過するときの流率を計測 した。表一 5 は、この流率と流入側歩行者等群の発 進流率（縁石線上）を比較した結果であり、計測断 面の流率は、発進流率に比べ低い值が得られた。

表-5 対向側歩行者等群の拡散 (実測)

\begin{tabular}{|c||c|c|}
\hline & $\begin{array}{c}\text { 対向側歩行者等群 } \\
\text { (流率 } \\
\text { (車道中央線断面) }\end{array}$ & $\begin{array}{c}\text { 流入側歩行者等 } \\
\text { 群進流率 }\end{array}$ \\
\hline \hline 亀戸 & 0.19 & 0.35 \\
\hline 小川町 & 0.20 & 0.34 \\
\hline 神保町 & 0.26 & 0.51 \\
\hline 西棵鴨 & 0.23 & 0.47 \\
\hline 日本橋 & - & 0.37 \\
\hline 本八丁堀 & 0.15 & 0.31 \\
\hline
\end{tabular}

そこで，歩行者等群の拡散は、物質移動の拡散現 象と同様に扱えると仮定した。即ち単位時間に単位 面積を通過して移動する流率が，これを考えている 地点でのポテンシャル差 (密度差) の1乗に比例す るとする。これは, 数)

$F=-\mu \frac{\partial \sigma}{\partial L} \quad(F:$ 流率 $\sigma$ :密度, $\mathrm{L}:$ 距離, $\mu$ :拡散係

であり, 各横断歩行者速度は横断中一定であると仮 定すると,

$$
F=-\alpha \frac{\partial F}{\partial L} \quad(\alpha: \text { 定数 })
$$

となり，上式は, 流率の緩和する速度が距離 $L$ に比 例することである。上式は、以下のように整理でき る。 


$$
\int \frac{d F}{F}=\int-\gamma \times d L \quad\left(こ こ て ゙, \quad \gamma=\frac{1}{\alpha} \text { と置く }\right)
$$

$$
\begin{aligned}
& \log |F|=-\gamma \times L+C \quad(C: \text { 定数 }) \\
& F= \pm e^{C} e^{-\gamma L}
\end{aligned}
$$

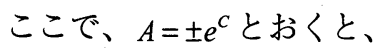

$$
F=A e^{-\mu} \quad(\mathrm{A}, \gamma \text { : 定数 })
$$

となる。

これを検証するために，亀戸 4 丁目のデータ使っ て歩行者等群 5 人以上存在するサイクルを 1 時間分 無作為に抽出し, $3 \mathrm{~m}$ 間隔 $(0,3,6 \cdots .18 \mathrm{~m}) 7$ 断面で横 断者等それぞれの通過時刻を計測した。この結果基 に各断面における流率と距離との関係に拡散現象が 存在するか検証をおこなった。

各サイクル単位のデータと全サイクル平均值のデ 一夕を用いて単回帰と負の指数回帰を行った。

サイクル単位では, 単回帰: $R=0.67, R^{2}=0.45$, 指数 回帰 : $R=0.72, \mathrm{R}^{2}=0.51$ となった

全サイクル平均值では, 単回帰: $R=0.99, R^{2}=0.98$, 指数回㷌 $: R \cong 1, R^{2} \cong 1$ となった（図 -5 参照)。

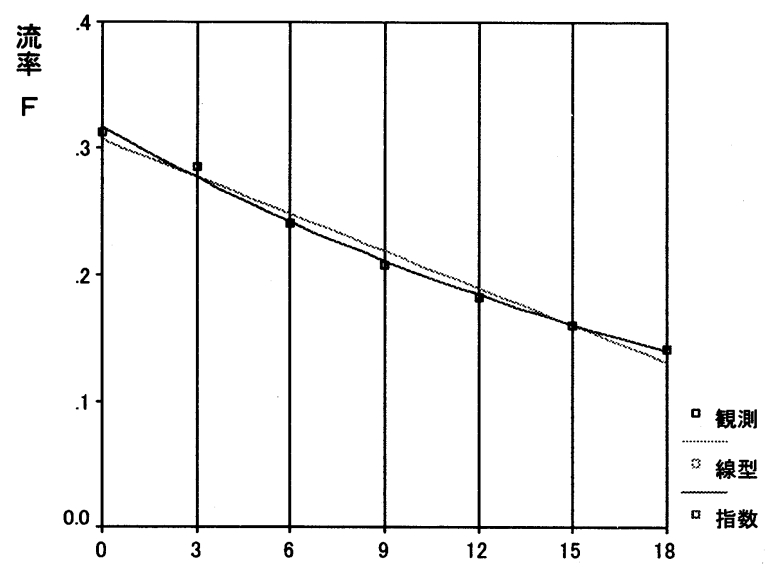

距離 $\mathrm{L}(\mathrm{m})$

\section{図一 5 サイクル平均の流率と距離の関係}

回帰式は以下のとおりである。

$$
F=0.31 e^{-0.045 L}
$$

ここで上記の0.31は歩道縁石の発進流率であり, 定 数 $\gamma=-0.045$ が歩行者等の拡散を表す定数として他 の地点でも定数が一定であるならば, 一般化が可能 である。そこで, 回帰式と車道中央線での計測値を 地点毎に比較したものが表一6である。結果は指数 回帰式と実測值は適合しており、対向側の流率は, 横断距離 $L$ を変数とした負の指数分布
$F=$ 歩道縁石発進流率 $\times e^{-0.045 L}$ で近似することが可能で ある。また, 歩行者のみで構成される拡散は自転車

\begin{tabular}{|c|r|r|}
\hline \multicolumn{3}{|c|}{ 表 -6 回㷌式と実測値の比較 } \\
\hline & 回熳值 & \multicolumn{1}{c|}{ 実測値 } \\
\hline \hline 亀戸4丁目 & 0.19 & 0.19 \\
\hline 小川町 & 0.19 & 0.2 \\
\hline 神保町 & 0.28 & 0.26 \\
\hline 西巣鴨 & 0.30 & 0.23 \\
\hline 本八丁堀 & 0.14 & 0.15 \\
\hline
\end{tabular}
が混入してい る時よりも小 さいことが示 された。回帰結 果は、定数 $\gamma=$ -0.033 (サイク ル単位: $r=0.52$, サイクル平均 $: r=0.97)$ である。

次に滞留人数 4 人以下のケースにおいて, 先に算 出した歩道端における 4 人以下の発進流率が拡散を 生じ車道中央線の流率となると仮定し, 定数を推定 した。この結果, 自転車が存在するケースでは定数 $\gamma=-0.096$, 歩行者のみで構成されるケースでは, 定 数 $\gamma=-0.072$ が得られた。

\section{（5）信号待ちしない歩行者の到着分布}

歩行者の到着分布は，ポアソン分布に従うと仮定 し、これを検証した。歩行者等群が流出し終えた後 の信号待ちしない歩行者等の最初の発生時間である 初期発生時間は、ポアソン過程では指数分布となる。 このため、初期発生時間について指数分布の適合度 について検証を行った。

流入側 6 地点のうち神保町を除く 5 地点において $5 \%$ 有意水準で仮説が棄却されない結果となった。

また, 対向側歩行者については, 歩行速度を 1.25 $\mathrm{m} /$ 秒と仮定し, 対向側横断距離 (車道中央線) で 除した值をシフトした指数分布の適合の検定を行っ た。この結果, 神保町と西巣鴨は, 仮説が裹却され ない結果となった。

以上のことから, 信号待ちをしない歩行者は, ポ アソン到着として取り扱うこととする。

\section{（6）対向側から左折交錯エリアに到達する歩行者。}

\section{自転車の出現}

本研究では, 対向側の歩行者等群の中から最初に左 折交錯エリアに到達する横断歩行者等の属性に着目 した。対向側から左折交錯エリアに到達する横断歩行 者等は、歩行者・自転車の速度差があるため、自転車 の有無によって、左折交錯エリアに到達する最初の横 断者等の属性が異なるためである。

実測結果は, 表一 7 に示すように自転車混入率の非 
常に少ない地点であっても, 左折交錯地点に到達する 最初の歩行者等の属性が自転車であるサイクルの比 率が高く、最初に到達する横断者の属性が, 左折車両 の通行の可否を決定する大きな要因となることから 解析を行った。

\begin{tabular}{|c|c|c|c|c|}
\hline \multirow[t]{3}{*}{ 表一 } & \multicolumn{4}{|c|}{ 自転車が左折交錯点に到達したサイクル数 } \\
\hline & $\begin{array}{l}\text { (1)調査サ } \\
\text { イクル数 }\end{array}$ & $\begin{array}{l}\text { 自転車混 } \\
\text { 入率(\%) }\end{array}$ & $\begin{array}{l}\text { (2)自転車の } \\
\text { 存在したサイ } \\
\text { クル数 }\end{array}$ & $\begin{array}{l}\text { (3)自転車が } \\
\text { 最初に到達し } \\
\text { たニサイクル数 }\end{array}$ \\
\hline & & & (2) $/(1)(\%)$ & (3) $/(2)(\%)$ \\
\hline 亀戸4丁目 & 154 & $44.9 \%$ & 142 & 123 \\
\hline & & & $92.2 \%$ & $86.6 \%$ \\
\hline 小川町 & 101 & $10.3 \%$ & 66 & 47 \\
\hline & & & $65.3 \%$ & $71.2 \%$ \\
\hline 神保町 & 149 & $5.2 \%$ & 94 & 59 \\
\hline & & & $63.1 \%$ & $62.8 \%$ \\
\hline 西巣鴨 & 138 & $32.5 \%$ & 101 & 75 \\
\hline & & & $73.2 \%$ & $74.3 \%$ \\
\hline 本八丁堀 & 153 & $16.7 \%$ & 82 & 65 \\
\hline & & & $53.6 \%$ & $79.3 \%$ \\
\hline
\end{tabular}

はじめに, 歩行者および自転車の速度分布は、対数 正規分布と仮定し、この仮定の検証を行った。亀戸 4 丁目において 5 人以上の歩行者等群の速度データか ら，カイ自乗検定を行った。得られたデー夕は，歩行 者 (平均值： $\mu=1.29$, 標準偏差： $\sigma=0.25$, デー夕数： $\mathrm{N}=179)$ ，自転車（ $\mu=2.27, \sigma=0.54, \mathrm{~N}=148)$ である。 検定の結果は, 有意水準 $5 \%$ で棄却されない結果とな った。

次に、自転車の存在の有無別サイクル数の推定を行 った。自転車の存在しないサイクル数を求めるに当た って，自転車の到着をポアソン分布と仮定した。これ は, 対象サイクル中に自転車が来ない確率に等しいこ とから,

$$
P=e^{-\frac{V t}{3600}}
$$

( $\mathrm{V}$ : 自転車交通量 (台 / 時), $\mathrm{t}$ ：サイクル長 $($ 秒 $)$ ) によって実測回数と比較検証した（表 $-8 ） 。$

\section{表一 8 自転車存在しないサイクル数}

\begin{tabular}{|c||r|r|}
\hline & \multicolumn{1}{|c|}{ 実測回数 } & \multicolumn{1}{|c|}{ 理論回数 } \\
\hline \hline 亀戸4丁目 & 12 & 6 \\
\hline 小川町 & 35 & 35 \\
\hline 神保町 & 55 & 51 \\
\hline 西巣鴨 & 37 & 32 \\
\hline 本八丁堀 & 54 & 55 \\
\hline
\end{tabular}

結果は、理論回数と実測回数が適合していること が示された。自転車の存在しないサイクル数の推定 は，自転車の到着確率分布にポアソン分布を仮定す ることとした。

さらに、自転車の存在するサイクルの速度分布の
推定を行った。歩行者と自転車の速度分布に対数正 規分布をあてはめ互いに独立と仮定し、これらを線 形結合した分布（混合分布）を考える。この分布は、 次式で表すことができ、結合パラメータ $w_{j}$ に自転車 混入率 $a$ と歩行者混入率 $1-a$ を適用すれば、自転車 と歩行者のそれぞれの混入率で重み佃けした 1 つの 確率分布と見なすことができる（図一6）。混入率は、 信号待ちしている歩行者・自転車の合計に対する歩 行者、自転車の割合である。

$$
\begin{aligned}
& f(v)=\sum_{j=1}^{N} w_{j} f_{j}(v) \\
& \sum_{j=1}^{N} w_{j}=1, \quad 0 \leq w_{j} \leq 1
\end{aligned}
$$

を満たすものである。

このとき歩行者と自転車の速度分布を線形結合し た分布の確率密度関数は次式で与えられる。

$f(v)=\frac{1-a}{v_{p} \xi_{p} \sqrt{2 \pi}} \exp \left[-\frac{1}{2}\left(\frac{\ln \left(v_{p}\right)-\lambda_{p}}{\xi_{p}}\right)^{2}\right]+\frac{a}{v_{b} \xi_{b} \sqrt{2 \pi}} \exp \left[-\frac{1}{2}\left(\frac{\ln \left(v_{b}\right)-\lambda_{b}}{\xi_{b}}\right)^{2}\right]$ ここで、 $v_{p}, v_{b}$ は、それぞれ歩行者と自転車の速度、 $\lambda$ は速度の期待值、 $\boldsymbol{\xi}$ は標準偏差である(図- 6 参照)。

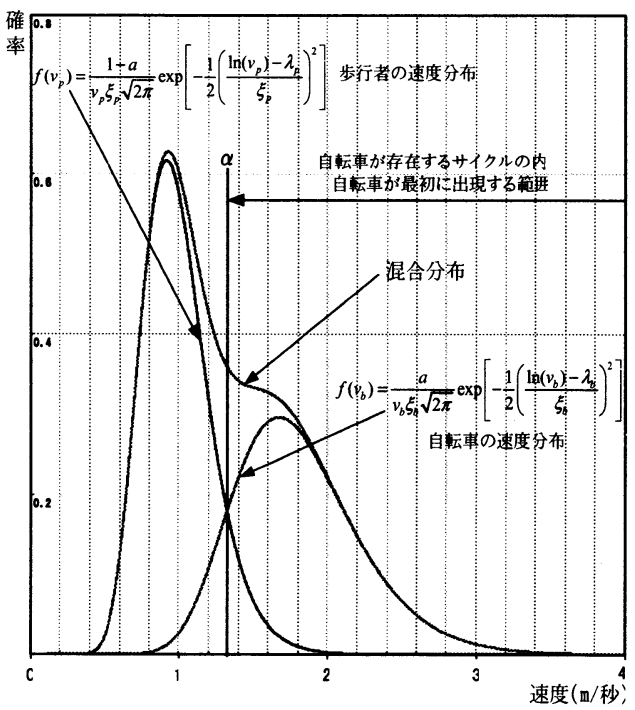

図-6 横断歩行者・自転車の速度分布と混合分布

歩行者と自転車の速度は、平均的に $\lambda_{p}<\lambda_{b}$ である が(例えば亀戸 4 丁目で歩行者の平均速度 $1.3 \mathrm{~m} /$ 秒、 自転車 $2.3 \mathrm{~m} /$ 秒)、図一 6 にみられるように自転車の 速度より高い速度の歩行者が存在し、常に自転車の 速度が歩行者の速度より高いとは限らない。したが 
って、左折との交錯エリアに最初に到達する歩行者 等が必ずしも自転車であるとはいえない。

そこで、左折交錯エリアに最初に自転車が到達す る確率を以下のように表すこととした。歩行者と自 転車の混入率で重み付けした速度分布が交わる時の 速度（図一 6 の $\alpha$ ）を求め、自転車の速度分布にお いてこの速度より高い速度領域の確率、すなわち

$$
P=\int_{\alpha}^{\infty} f_{b}(v) d v
$$

を上記の確率とした。ここで、 $f_{b}(v)$ は、自転車の速 度の確率密度関数である。

上記の仮説を検証するために，実測デー夕を基に 分析を行った。前述したように、歩行者・自転車別 に混入率で重み付けした対数正規分布の交点 $\alpha$ より 高い速度領域の確率を理論出現確率として求め（交 点 $\alpha$ は数值計算によって算出）、実測出現確率（自転

\begin{tabular}{|c|c|c|c|}
\hline \multicolumn{3}{|c|}{ 表 -9 自転車の出現確率の検証 } & 車のいた \\
\hline & 実測出現確率 & 理論出現確率 & \\
\hline 亀戸4丁目 & $87 \%$ & $88 \%$ & \\
\hline 小川町 & $71 \%$ & $71 \%$ & \\
\hline 神保町 & $62 \%$ & $63 \%$ & \\
\hline 西巣鴨 & $74 \%$ & $84 \%$ & \\
\hline 本八丁堀 & $79 \%$ & $77 \%$ & リア \\
\hline
\end{tabular}

初に到達したサイクルの割合）と比較したのが表一 9 である。理論值は、実測によく適合することがわ かった。

（7）対向側から左折交錯点に到達する歩行者・自転 車の速度の推定

対向側から到達する歩行者等による左折車両の閉 塞は, 左折交錯点に対向側から到達する最初の横断 者によって発生する。本研究では, 対向側から左折 交錯点に到達する最初の横断者の速度を推定するた めに順序統計量を用いた。歩行者等の滞留人数 $(n)$ から n 番目順序統計量（最も速度が高い）を求め, この時の速度を対向側から左折交錯エリアに最初に 到達する歩行者または自転車の速度の推定値とする ものである。

はじめに, 順序統計量について概説する。

確率密度関数 $f(v)$ 、累加分布関数 $F(v)$ をもつ母集 団から $\mathrm{n}$ 個の観測值が得られたとき、これらの観測 值を昇順に並び換えたものであり、 $i$ 番目の変量 $v_{i}$ を $i$ 番目順序統計量という。これら $\mathrm{n}$ 個の順序統計量を
表す確率変数を考えると次のことが成り立つ。

$i$ 番目順序統計量が $v_{i}$ という值を取るとき，これに 対する非超過確率 $F\left(v_{i}\right)$ は,

$$
F\left(v_{i}\right)=\int_{-\infty}^{v_{i}} f(v) d v
$$

であり，超過確率 $W\left(v_{i}\right)$ は，

$$
W\left(v_{i}\right)=\int_{v_{i}}^{+\infty} f(v) d v=1-F\left(v_{i}\right)
$$

である。変量 $v$ が $v_{i}$ のときの確率要素 $\left(v_{i}\right.$ と $v_{i}+d v$ と の間に生ずる確率) は,

$$
d F\left(v_{i}\right)=f\left(v_{i}\right) d v
$$

そうすると, $i$ 番目順序統計量 $v_{i}$ の確率要素は,

$$
f\left(v_{i}\right) d v=\frac{n !}{(i-1) !(n-i) !} F\left(v_{i}\right)^{i-1} W\left(v_{i}\right)^{n-i} f\left(v_{i}\right) d v
$$

で表される。

ここで, $F\left(v_{i}\right)$ の期待値 $E\left(F\left(v_{i}\right)\right)$ を考えると,

$E\left(F\left(v_{i}\right)\right)=\int_{0}^{1} F\left(v_{i}\right) \times \frac{n !}{(i-1) !(n-i) !} F\left(v_{i}\right)^{i-1} W\left(v_{i}\right)^{n-i} d F\left(v_{i}\right)$

$=\frac{n !}{(i-1) !(n-i) !} \int_{0}^{1} F\left(v_{i}\right)^{i}\left\{1-F\left(v_{i}\right)\right\}^{n-i} d F\left(v_{i}\right)$

である。

ここで, $\alpha, \beta$ をパラメータとするベータ関数 $B(\alpha, \beta)$ は,

$$
\int_{0}^{1} F\left(v_{i}\right)^{\alpha-1}\left[1-F\left(v_{i}\right)\right]^{\beta-1} d t=B(\alpha, \beta)
$$

であり、

$$
B(\alpha, \beta)=\frac{\Gamma(\alpha) \Gamma(\beta)}{\Gamma(\alpha+\beta)}
$$

を用いて

$$
\begin{aligned}
E\left(F\left(v_{i}\right)\right) & =\frac{n !}{(i-1) !(n-i) !} B(i+1, n-i+1) \\
& =\frac{n !}{(i-1) !(n-i) !} \times \frac{\Gamma(i+1) \Gamma(n-i+1)}{\Gamma(n+2)}
\end{aligned}
$$

となる。ガンマ関数は i が自然数のとき、 $\Gamma(i)=(i-1)$ ! であるから, $F\left(v_{i}\right)$ の期待值として

$$
E\left(F\left(v_{i}\right)\right)=\frac{i}{n+1}
$$

が得られる。 
この期待値を改めて, $F\left(v_{i}\right)=\frac{i}{n+1}$ と表し, これ が小さいほうから数えて $i$ 番目に位置する $i$ 番目順 序統計量 $v_{i}$ の期待値である（この式によって期待値 を求める方法を平均ランク法と呼んでいる)。

順序統計量を用いて、サイクル平均滞留歩行者等 群 $n$ 人の時の $n$ 番目（対向側歩行者群の中で最も速 度が高い) の速度を推定した。

この $n$ 番目の歩行者群等の $F\left(v_{n}\right)$ は, $\frac{n}{n+1}$ であり, この $F\left(v_{n}\right)$ の時の $v_{n}$ を先頭歩行者等の速度とする。ま た, $n$ が小さい場合 $(n<20)$ には,メジアンランク 法が適合しており，この近似式として，

$$
F\left(v_{n}\right)=\frac{n-0.3}{n+0.4} \quad(i=1,2,3 \ldots . . n)
$$

がある（A.Benard \&E.C.Bos_Levenbach(1953)）。

従って, 信号待ちする対向側横断歩行者等のサイ クル当りの平均滞留人数に応じて平均ランク法とメ ジアンランク法を用いて, 最も早い横断歩行者等の 速度を推定することとした。

平均ランク法: $\quad E\left(F\left(v_{i}\right)\right)=\frac{i}{n+1} \quad($ for $n>20)$ メジアンランク法： $M\left(F\left(v_{i}\right)\right)=\frac{i-0.3}{n+0.4} \quad($ for $n \leq 20)$

次に, 亀戸 4 丁目交差点の 1 時間データを基にし たサイクル毎の滞留人数と速度順による発進順位の 関係を図一 7 に示す。最も高い又は 2 番目に高い速 度の横断者の発進順位は 2 サイクルを除き 1 位又は

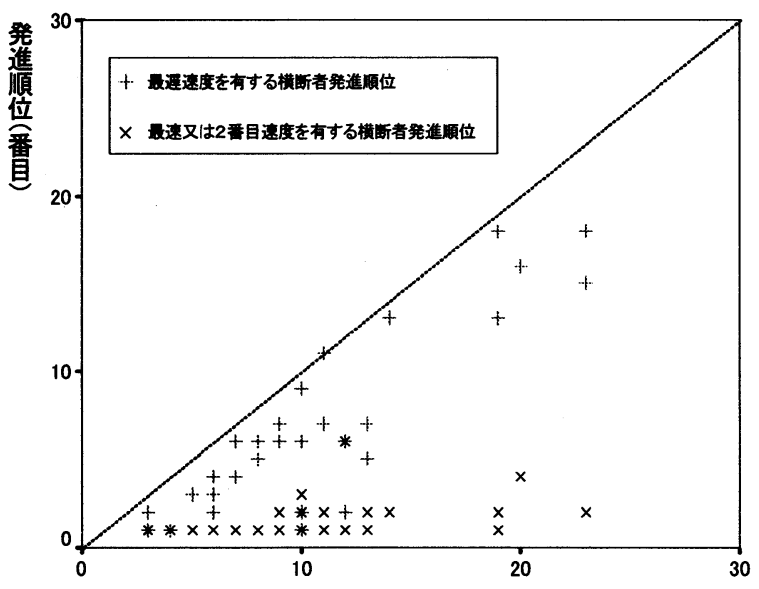

滞留人数(人)

図-7 滞留人数と発進順位の関係
2 位である。一方, 最も速度の遅い横断者の発進順 位は規則性が見出せないが, 傾向として滞留人数の 後半に発進することが伺える。この事実を踏まえて 対向側から最初に左折交錯点に到達する歩行者等は, 最初に横断を開始する歩行者・自転車であると仮定 し, 横断歩行者等の速度を推定した。横断歩行者等 群の速度分布を対数正規分布で仮定し、最速歩行者 または最速自転車の速度の累加確率を順序統計量に メジアンランク法または平均ランク法を用いて、こ の時の累加確率に対応する最速者速度を算出した。 最速者の速度推定值と実測結果は, 表一 10 に示す。

表一10 最初に左折交錯点に到達する歩行者等の実 測結果と推定值の比較

\begin{tabular}{|c|c|c|c|c|c|c|c|c|}
\hline & \multicolumn{4}{|c|}{ 自芸苇が存在しないケース } & \multicolumn{4}{|c|}{ 自的真が存在するケース } \\
\hline & 平均歩行 & 萑 & 定焦 & 实测侐 & 平均自宗 & 推资 & 定值 & 寒测傅 \\
\hline & $\begin{array}{l}\text { 者数(人) } \\
\text { サイクル) }\end{array}$ & 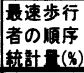 & \begin{tabular}{|l} 
曼速歩行 \\
者速度 \\
$(\mathrm{m} /$ 秒
\end{tabular} & \begin{tabular}{|l} 
平均速 \\
歩行者速 \\
度 $(\mathrm{m} /$ 秒 $)$
\end{tabular} & $\begin{array}{l}\text { 車数(人) } \\
\text { サイクル) }\end{array}$ & 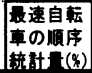 & 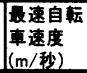 & $\begin{array}{l}\text { 平均德速 } \\
\text { 自転真速 } \\
\text { 度(m/秒) }\end{array}$ \\
\hline & 7.0 & $90.5 \%$ & 1.62 & 1.90 & 3.2 & $79.4 \%$ & 2.67 & 2.45 \\
\hline & 9.1 & $92.6 \%$ & 1.67 & 1.90 & 1.4 & $50.0 \%$ & 2.21 & 2.40 \\
\hline 神保町 & 20.4 & $96.6 \%$ & 1.79 & 1.80 & 1.6 & $70.8 \%$ & 2.51 & 2.40 \\
\hline 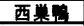 & 4.8 & $87.0 \%$ & 1.56 & 1.52 & 2.0 & $70.8 \%$ & 2.51 & 2.00 \\
\hline 本八丁幄 & 4.2 & $84.1 \%$ & 1.54 & 1.34 & 1.1 & $50.0 \%$ & 2.21 & 2.10 \\
\hline
\end{tabular}

自転車が存在しないケースと自転車が存在するケ ースのどちらにおいても、推定值と実測值は、おお むね適合していることが示された。この結果から， 対向側から左折交錯エリアに最初に到達する歩行者 等の速度の推定方法として順序統計量を用いること とした。

6. まとめ

\section{(1) 横断歩行者等の発進流率}

流入側の横断歩行者等群は，図－2で示したよう に, 平均 1 秒の発進遅れで発生し, 歩行者等群が左 折交錯エリアを通過する間中、左折車両は閉塞され る。この時の左折閉塞時間は、(歩行者滞留人数 /(発 進流率 $\times$ 横断歩道幅員) で算出される。発進流率は, $f=0.012 N+0.251$ ( 5 人以上)であり, その後信号待 ちしない歩行者等群の発生は、ポアソン分布で近似 できる。

\section{(2)対向側の横断歩行者等群の流率}

対向側の横断歩行者等群の発進は、平均 1 秒の発 進遅れで発進し、滞留人数から対向側縁石線におけ る発進流率を算出し, 次に歩行者等群が左折交錯工 リアに到達する時の流率を推定する。流率は、横断 距離を変数とした拡散現象で表すことが示された。 
流率の推定方法は、左折交錯エリアまでの距離を L とし、負の指数関数 (対向側縁石発進流率 $\times e^{-0.045 L}$ ) を用いて算出する ( 5 人以上)。歩行者のみで構成さ れるサイクルでは、(対向側縁石発進流率 $\times e^{-0.033 L}$ ) を用いて流率を推定する ( 5 人以上)。

(3)対向側から左折交錯エリアに最初に到達する歩 行者等の属性の推定

はじめに、自転車交通量を用いて横断歩行者等の 中に自転車の存在するサイクル数を推定する。

次に、自転車の存在するサイクルの中で、左折交 錯エリアに最初に到達する歩行者等が自転車である 確率は、自転車と歩行者の混入率で重み付けした対 数正規速度分布を用いて推定した。自転車の出現確 率の算出方法は、2つの速度分布の交点 $\alpha$ 以上であ る自転車の速度分布の積分值である。

\section{(4)左折交錯エリアに最初に到達する横断歩行者等 の速度の推定}

左折交錯エリアの最初に到達する横断歩行者等の 速度は、順序統計量を用いて推定した。

(5) 左折交錯エリアにおける横断歩行者等が左折車 両を閉塞する時間の推定

流入側歩行者等群の閉塞時間は、(1)の結果を用い て左折交錯エリアの到達時間および左折交錯エリア からの流出時間の算定を行う。

一方、対向側歩行者等群の閉塞開始時間は、 (2)，(3)，(4)で示したように自転車交通量と自転車 混入率を用いて左折交錯エリアに最初に到達する歩 行者等の属性及び速度を推定し閉塞開始時間の算定 を行う。対向側歩行者等群の左折車両閉塞時間は、 歩行者等群の左折交錯エリア通過終了時刻から歩行 者等群の先頭横断歩行者等の到達時刻を減じた值で
算定できる。

本研究で案出した手法は, 左折車両を閉塞する時 間の算出をする目的で構築したものであるが，信号 交差点における自転車交通の影響評価, 横断歩道幅 員の決定や变更に伴う影響評価, 歩車分離信号機の 計画・評価，信号現示企画の設計，車線運用方法の 計画・評価等に応用できると考える。

今後の課題としては, 本モデルの精度検定および左折車 両が通行可能な歩行者ギャップの推定モデルの構築を図

り，左折容量の推定手法の確立を図ることである。

最後に, 歩行者本研究は財団法人三井住友海上福祉財団 平成 13 年度交通安全・高齢者福祉助成金を得て実施した ことを記して謝意を表する。

\section{参考文献}

1)信号交差点における転向半径と転向角度が左折飽和 交通流率に与える影響について、土木計画学研究・論文 集,Vol.25, H14.6, 河合芳之, 鹿田成則, 片倉正彦, 大 口敬

2)交通工学研究会編: 平面交差の計画と設計一基礎編一, 昭和 59 年

3)池ノ上慶一郎,斉藤威 : シミュレーションのための信 号交差点における転向車両の横断歩行者による停止確 率の算出法,科学警察研究所報告交通編, 1972

4)交通工学研究会編：交通信号の手引,平成 6 年

5) Karl-Lennart Bang, Swedish Capacity Manual: Part 3.

Capacity of Signalized Intersections ,TRR667, 1978

6) Andrzej Tarko \& Stanislaw Gaca, Pedestrians at signalized Intersections, Highway Capacity and Level of Service, 1991

7)Handbuch für die Bemessung von

Straßenverkehrsanlagen(HBS2001), FGSV, Deyember 2001

8) JOSEPH S. MILAZZO II, NAGUI M. ROUPHAIL,

JOSEPH E. HUMMER ,AND D. PATRICK ALLEN, Effect of Pedestrians on Capacity of Signalized

Intersections ,TRR 1646,1998

9)Transportation Research Board ,Highway Capacity

Manual(HCM2000),2000

10)S.Teply ,D.I Allingham, D.B.Richardson,

B.W.Stephenson, Canadian Capacity Guide for Signalized Intersections , 1995

11)松本弘之,村田隆裕: 歩行目的別横断歩行者流の調査 結果について,科学警察研究所報告交通編, 1980 
信号交差点における左折交通に及ぼす横断歩行者及び自転車の特性と定量化について

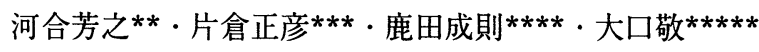

信号交差点の流入部は, 最外側車線を直進・左折混用車線とし, 横断歩行者・自転車（以下：横断歩行者等）と 同一現示で処理することが一般的である。このような最外側車線は，横断歩行者等の影響により左折車両の閉塞が 生じ，併せて直進車両の消極的な車線選択による交通容量の低下が見られる。

本研究は, 左折交通流率の影響要因である横断歩行者等の量や行動特性に着目し, 横断歩行者等と左折車両が交 錯する地点における横断歩行者等の実態とその特性について明らかにし, 横断歩行者等の横断挙動の定量化を行っ たものである。

信号待ちの状態から発進する歩行者等の流率は, 滞留人数を変数とした関数で近似でき, 横断距離を变数とした 拡散現象で表すことを示した。さらに、横断歩行者等の自転車混入率を用いて, 最初に左折車両と交錯する地点に 到達する歩行者等の属性の推定手法を案出し, この歩行者等の横断速度算出手法の導出を行った。これらの結果を 統合して、横断歩行者等が左折車両を閉塞する時間の算出方法を確立した。本研究で案出したモデルは、信号制御 を中心とする歩車分離信号の導入の効果やその基準の設定等、平面交差点の設計に供すると考える。

\section{Characteristics and Quantitative Analysis of Crossing Pedestrians and Bicycles Affecting the Left-turn Flow at Signalized Intersections *}

By Yoshiyuki KAWAI** Masahiko KATAKURA*** Shigenori SHIKATA**** Takashi OGUCHI

In this Paper, The purpose of this paper is to investigate the factors affecting saturation flow rate of left-turn traffic. The actual conditions and characteristics of pedestrians/bicycles at the conflict area where pedestrians/bicycles and left-turn vehicles cross are clarified in order to quantify the behavior of pedestrians/bicycles. The model devised in this study is expected to contribute to the development of signalized intersection planning. 